\title{
Água-De-Coco com Potencial Probiótico
}

\author{
Claudia Dorta (I), Maria Beatriz Silva (I), Alice Yoshiko Tanaka (I), \\ Gustavo Lana Soares (I) \\ (I) Fatec Marília-SP - Fatec "Estudante Rafael Almeida Camarinha" Marília-SP (Av. Castro \\ Alves, 62, Somenzari, Marília-SP, 17506000)
}

\section{Resumo}

Os alimentos probióticos são constituídos de micro-organismos vivos que administrados em quantidades adequadas conferem benefícios à saúde do hospedeiro. Os produtos lácteos são os alimentos mais usados como veículos de probióticos, porém o leite está entre os produtos mais comumente envolvidos em casos de alergias e intolerâncias. Este trabalho teve como objetivo obter bebida com potencial probiótico, adicionando Lactobacillus acidophilus em água-de-coco comercial refrigerada, além de verificar poder de inibição da bactéria sobre leveduras contaminantes. As variações amostrais deste experimento foram água-de-coco refrigerada comercial adicionada de: a) L. acidophilus na ordem de $10^{9} \mathrm{UFC} / \mathrm{mL}$; b) L. acidophilus na ordem de $10^{9} \mathrm{UFC} / \mathrm{mL}$ e Saccharomyces cerevisiae a $10^{5}$ $\mathrm{UFC} / \mathrm{mL}$ para teste de inibição/competição; c) sem adição de microorganismos (controle). Todos os experimentos foram feitos em condições assépticas, em Erlenmeyers vedados com tampão algodão e mantidos refrigerados a $4^{\circ} \mathrm{C}$ durante 25 dias. Nessas variáveis amostrais fez-se análises de $\mathrm{pH}$, acidez total e microbiológicas: mesófilos aeróbios, bolores, leveduras e viabilidade celular de L. acidophilus. Testes de resistência aos sais biliares $(0,3$ e $0,6 \%)$ e ao ácido clorídrico ( $\mathrm{pH} 2,0,2,5$ e 3,0 por $2 \mathrm{~h}$ ) foram feitos com L. acidophilus em 15 e 25 dias de armazenamento das amostras. As amostragens foram executadas em triplicata para a análise estatística dos dados. Após os experimentos verificou-se pouca variação de pH e acidez da bebida. L. acidophilus teve viabilidade celular desejável, em todas as amostras analisadas, durante os 25 dias de armazenamento a $4{ }^{\circ} \mathrm{C}$; até mesmo após o teste com 0,3 e $0,6 \%$ de sais biliares e do tratamento 
ácido durante o armazenamento. A água-de-coco comercial refrigerada usada não apresentou boa qualidade higiênica, pois foram encontrados mesófilos aeróbios e leveduras acima de limites recomendados. L. acidophilus exerceu efeito inibitório sobre leveduras naturais e adicionadas na água-de-coco comercial. Em 25 dias de armazenamento, o crescimento das leveduras na amostra sem adição de probiótico foi superior a $70 \%$ quando comparado às amostras com adição da bactéria probiótica. Esta bebida apresentou potencial probiótico e mostrou capacidade de estender a vida de prateleira do produto, além de ser uma alternativa viável aos intolerantes ou alérgicos ao leite.

Palavras-Chave: Alimentos funcionais, água-de-coco, Lactobacillus acidophilus, probiótico

Agência de Fomento: 